\title{
Analysis of Enzyme Activities of the Gut Bacterial Communities in Labeo rohita fed Differentially Treated Animal Fleshing Diets
}

\author{
C. Sumathi, D. Mohana Priya, V. Dilli Babu and G. Sekaran*
}

Environmental Technology Division, Central Leather Research Institute (CSIR) Chennai- 600 020, Tamil Nadu, India

\begin{abstract}
The present investigation includes isolation, enumeration and comparison of the gut microbial flora of Labeo rohita fed differentially treated Animal Fleshing (ANFL) as a sole protein source in their diets and related increase in enzyme secretion. ANFL is the proteinaceous tannery solid waste generated during leather processing and inclusion of ANFL in aqua feed will pave way for the novel alternative cheaper protein source in replacement of fish meal. Six experimental diets were formulated with differentially processed ANFL. The isolates from the gut extract were qualitatively screened and quantitatively assayed for amylase, cellulase, lipase and protease activities. The total culturable bacterial count $\left(10 \times 10^{7} \mathrm{CFU} / \mathrm{g}\right)$ as well as the proteolytic bacterial count $\left(27 \times 10^{6} \mathrm{CFU} / \mathrm{g}\right)$ was high in the fish gut fed with diet 5 containing the fermented ANFL. Almost all the bacterial isolates possesses protease activity in which strains (FF5, CF3and CF4) isolated from the diet 5 (287U) and 7 (282U) exhibited highest activities. Maximum cellulase (FF2), amylase and lipase (RF6) activity were observed in the strains isolated from the diets 5 and 1 (78U, $186 \mathrm{U}$ and $97 \mathrm{U}$ ). This study proves the existence of diet dependent enzyme producing bacterial community in the gut of Labeo rohita through SEM analysis and the information generated from the present study might contribute towards utilization of enzyme producing bacterial isolates as probiotic and in better feed formulations at low cost for rohu incorporating the tannery solid waste ANFL as a protein source.
\end{abstract}

Keywords: Gut microbial enzymes; Animal Fleshing (ANFL); Labeo rohita

Abbreviations: ANFL - Animal fleshing, SMA -skim milk agar, CMC Carboxy methyl cellulose agar, SA - Starch agar, TA -Tween 20 agar

\section{Introduction}

The micro-environment of the digestive tract of fish confers a favorable growth for the microorganisms [1-3] by providing ecological niche for these organisms [4]. The microbiota of fish has been shown to be highly dependent on the bacterial colonization during early development, environmental conditions, nutrient composition and dietary changes $[5,6,62]$. These microorganisms grow upon the food absorbed by the host animal, digestive secretions and fragments scaled off the mucosal epithelium [7] and have a better chance of survival [8].

The indigenous microflora of fish in aquaculture has previously been studied for several purposes $[19,21,22]$.and differs from ovary skin and liver [71]. Previous studies include descriptions of microbial spoilage [9,72], relationship between environment and fish microflora [10], monitoring of changes in fish farms [11], nutritional role of the intestinal flora [12] and the antibiotic resistance profile of the indigenous flora [13]. Preceding research suggests that digestive enzymes present in fish digestive tract can elucidate some aspects of their nutritive physiology [73] and thus be supportive to develop nutritional strategies for fish feeding and diet formulation [14-17].

In general, the bacterial flora of the gastrointestinal tract with diversified enzymatic potential plays a vital role in major part of the metabolism of the host animal [18].From the studies made so far, it appears that different species of fish and crustaceans have a specific resident gut microbiota $[60,62,85]$.and the isolated species include Acinetobacter spp, Enterobacter spp. and Pseudomonas spp. in trout (Oncorhynchus sp.); Aeromonas spp., Flavobacterium spp. and Lactobacillus spp. in Arctic charr (Salvelinus alpines) [58]. Enterovibrio spp. from the intestinal tract of turbot (Scophthalamus maximus) [59]. Vibrio spp., Bacillus sp., Pseudomonas sp., Photobacterium sp. and Plesiomonas sp. in white shrimp, Fenneropenaeus (Penaeus) indicus
[60]. P. glacincola in the hind-gut of Arctic charr [6]. and Atlantic cod [22]. Vibrio species from gut of halibut larvae [69] and Atlantic cod [74,22]. P. phosphoreum farmed Norwegian salmon [65]. and UK halibut [60]. Providencia sp. and Shewanella sp.[63]. However, the information regarding the enzyme producing intestinal bacteria related to feed in fish is scarce [16].

The inter-relationships between the microbiota and the host are clearly important as the health and imbalance between these systems appears to drive a wide range of mucosal and systemic immunemediated disorder [26,27]. Several authors revealed the presence of microbiota in fish gut [19-22]. and enzyme producing bacteria in the digestive tract of L. rohita $[23,24]$. The use of such beneficial bacteria has a long tradition in the animal husbandry [25]. However, the research based on gut microbial population in fish species and digestive enzymes related to animal fleshing feed source, their significance as a means to determine assimilating capacity is perhaps nil.

Animal protein sources present good essential amino acids balance [76].but costs and heterogeneous composition repeatedly limit their use, and the use of alternative sources is required [77]. Hence, amino acid rich proteinaceous tannery solid waste animal fleshing was used as a protein source in fish feed formulation. India is one of the leading

*Corresponding author: Dr. G.Sekaran Deputy Director and Head Environmental Technology Division,Central Leather Research Institute,Adyar, Chennai - 600 020,Tamil Nadu, India, Tel: +91-44-24911386; Fax: +91-44-24410232; E-mail: joymoon2@gmail.com

Received July 10, 2011; Accepted December 07, 2011; Published December 12,2011

Citation: Sumathi C, Mohana Priya D, Dilli Babu V, Sekaran G (2011) Analysis of Enzyme Activities of the Gut Bacterial Communities in Labeo rohita fed Differentially Treated Animal Fleshing Diets. J Microbial Biochem Technol 3: 112000. doi:10.4172/1948-5948.1000061

Copyright: (c) 2011 Sumathi C, et al. This is an open-access article distributed under the terms of the Creative Commons Attribution License, which permits unrestricted use, distribution, and reproduction in any medium, provided the original author and source are credited 
countries in freshwater aquaculture. In 1998, the total production of freshwater fish was 1.7 million tons of which carps contributed about 87\%. Rohu (Labeo rohita) is the most important Indian major carp that enjoys high consumer preference in many states with high protein conversion ratio [75]. Hence, the focal theme of the present work was to evaluate the enzyme producing microbiota and activities of enzymes in the digestive tract of rohu, Labeo rohita fed differentially treated animal fleshing incorporated diets.

\section{Materials and Methods}

\section{Acclimatization of fish to experimental conditions}

Labeo rohita fingerlings (average weight $5 \mathrm{~g} \pm 0.25 \mathrm{~g}$ ) were obtained from nearest farm in Chennai (India) and acclimatized in $1000 \mathrm{~L}$ cylindrical tanks filled with dechlorinated tap water for 15 days with control feed. Three hundred and fifty fingerlings were selected for the study and divided into six experimental groups and one control. Each group of 50 fingerlings was again divided into two equal duplicate subgroups. Fish were fed twice daily (9:00 a.m. and 17:30 p.m.) to apparent satiation. The fish were fed $3 \%$ of their body weight twice a day. The limed animal fleshing was collected from a tannery processing raw goat skins/cow hides into leather in Chennai. Briefly, the animal fleshing was subjected to various optimized treatments (data not shown) such as microwave for 60 minutes, ozonation for 60 minutes, soaking in $\mathrm{H}_{2} \mathrm{O}_{2}$ for 60 minutes, fermentation with bacterial mixed culture from the fish gut and autoclaving (Table 1). The impact of nutritional effects on gut flora and gut enzyme was studied on $60^{\text {th }}$ day.

\section{Microbiological Examination of Gut Flora}

Fish from each experimental set was collected, after $36 \mathrm{hrs}$ of starvation. The fish was sacrificed and surface sterilized using $1 \%$ (w/v) iodine solution. For microbiological examination and enzyme analysis the intestine was dissected on ice slab in sterile condition. The intestine samples were then homogenized in a surface sterilized mortar and pestle. The homogenized samples were serially diluted (ten folds) with sterile chilled buffered saline solution. Diluted samples $(0.1 \mathrm{ml})$ were spread aseptically within a laminar airflow on sterilized Schaedler HiVegTM Agar (Hi media, India) to determine the total culturable gut heterotrophic bacterial population. Spread plate technique was used to

\begin{tabular}{|c|c|c|c|c|c|}
\hline $\begin{array}{l}\text { Experimental } \\
\text { diets }\end{array}$ & $\begin{array}{c}\text { Rice } \\
\text { Bran } \\
(\mathrm{g})\end{array}$ & $\begin{array}{l}\text { Wheat } \\
\text { Flour } \\
(\mathrm{g})\end{array}$ & $\begin{array}{c}\text { Oil } \\
\text { Cake } \\
(\mathrm{g})\end{array}$ & $\begin{array}{c}\text { Sunflower } \\
\text { Oil } \\
(\mathrm{g})\end{array}$ & $\begin{array}{l}\text { Protein Source } \\
\qquad(35 \mathrm{~g})\end{array}$ \\
\hline DIET 1 & 20 & 20 & 10 & 1 & $\begin{array}{l}\text { Raw ANFL } \\
\text { (rf) }\end{array}$ \\
\hline DIET 2 & 20 & 20 & 10 & 1 & $\begin{array}{l}\text { Microwave treated ANFL } \\
(\mathrm{mf})\end{array}$ \\
\hline DIET 3 & 20 & 20 & 10 & 1 & Ozone Treated ANFL \\
\hline DIET 4 & 20 & 20 & 10 & 1 & $\begin{array}{c}\mathrm{H}_{2} \mathrm{O}_{2} \text { treated ANFL } \\
\text { (hf) }\end{array}$ \\
\hline DIET 5 & 20 & 20 & 10 & 1 & $\begin{array}{l}\text { Fermented ANFL } \\
\text { (ff) }\end{array}$ \\
\hline DIET 6 & 20 & 20 & 10 & 1 & $\begin{array}{c}\text { Autoclave ANFL } \\
\text { (af) }\end{array}$ \\
\hline CONTROL & 20 & 20 & 10 & 1 & $\begin{array}{l}\text { Fish meal } \\
\text { (cf) }\end{array}$ \\
\hline
\end{tabular}

*Vitamin premix $\mathrm{mg} / \mathrm{g}$ : retinol palmitate $400,000 \mathrm{IU}$, thiamine 5,riboflavin 4,niacin 20 ,.folic acid,2, pyridoxine,6,cyanocobalamine 5, ascorbic acid,12,cholecalciferol $55,000 \mathrm{IU}$, tocoferol 3 , biotin 0.3 ,choline chloride 90,pantothenic acid ,10. Mineral premix for $100 \mathrm{~g}$ calcium phosphate dibasic, 7.35 ; citric acid,0.03; ferrous sulphate $50 \mathrm{mg}$ magnesium oxide 3 ; manganese sulphate 0.7 ; potassium phosphate dibasic, 9 ; sodium chloride

Table 1: Aqua feed composition. isolate and enumerate protease, cellulase, amylase and lipase producing bacterial population, diluted samples $(0.1 \mathrm{ml})$ was poured on skim milk agar (SMA), Carboxy methyl cellulose agar (CMC), Starch agar (SA) and Tween 20 agar (TA) plates, respectively. Culture plates were incubated at $37^{\circ} \mathrm{C}$ for 48 hours and were subsequently examined for the development of bacterial colonies. It was assumed that the micro flora, which had formed colonies on the SA plate, had amylolytic activity, CMC- cellulolytic, SMA -proteolytic and TA plates- lipolytic activities. Colony numbers per unit sample volume of gut homogenate were determined by multiplying the number of colonies formed on each plate by the reciprocal of dilution. The well separated colonies producing various extracellular enzymes with apparently different morphology were streaked separately on Tryptone Soy Agar (TSA) (Hi Media, India) plates to obtain pure cultures [74]. Single, isolated colonies from the streaked plates were transferred to TSA slants for further study. Chemicals used for analysis were procured from Merck and Hi Media, India. No conflict of interest existed during the entire study period.

\section{Qualitative assay for enumeration of enzyme producing bacteria}

The intensity of extracellular enzyme production by the pure cultures was determined on agar plates with selective media. For extracellular amylase production, the samples were inoculated on SA plates and incubated at $37^{\circ} \mathrm{C}$ for $48 \mathrm{~h}$. The culture plates were then flooded with $1 \%$ Lugol's iodine solution [56]. formation of transparent zone surrounding the colony indicated amylase activity. Similarly, for extra-cellular protease, the samples were inoculated on SMA plates and incubated at $37^{\circ} \mathrm{C}$ for $24 \mathrm{~h}$. The appearance of a clear zone around the colony confirmed the proteolytic activity. For determination of cellulase production, the samples were grown on CMC plates at $37^{\circ} \mathrm{C}$ for $24 \mathrm{~h}$ and flooded with $0.1 \%$ Congo red dye and destained with $1 \mathrm{M}$ sodium chloride [57]. Congo red selectively binds with unhydrolyzed CMC. Appearance of clear halo due to the presence of hydrolyzed CMC surrounding bacterial colony indicated cellulase production in the medium. For assaying lipase activity the samples were inoculated on the TA plates. Formation of calcium laurate white crystals due to the reaction between the fatty acids released and $\mathrm{CaCl}_{2}$ present in the medium around the colonies confirm the lipase activity of the colony.

\section{Media composition}

Schaedler HiVegTM Agar $\left(\mathrm{g} \mathrm{L}^{-1}\right)$ : Hiveg hydrolysates, 5.67; Hiveg peptone No.3, 5.00; Papaic digest of soyabean meal, 1.00; Yeast extract, 5.00; Dextrose, 5.83; Sodium chloride,1.67;Dipotassiumhydrogen phosphate, 0.83; Tris hydroxymethyl aminomethane, 3.00; L-cysteine, 0.40; Ferric pyrophosphate, 0.01; Agar, 15; pH 7.6; TSA medium (HIMedia, Chennai, India) ( $\left.\mathrm{g} \mathrm{L}^{-1}\right)$ : Pancreatic digest of casein, 15; Papaic digest of soyabean meal, 5 ; NaCl, 5; Agar, 15; pH 7; SA medium (g $\left.\mathrm{L}^{-1}\right)$ : Beef extract, 5; Peptone, 5; $\mathrm{NaCl}, 5$; Starch (soluble), 2; Agar, 20; $\mathrm{pH}$ 7; CMC medium (g L $\left.{ }^{-1}\right)$ : Beef extract, 5; Peptone, 5; $\mathrm{NaCl}, 5$; Carboxymethyl cellulose, 2; Agar, 20; pH 7; SMA (g L-1): Skim milk 20; $\mathrm{NaCl}$ 5; Agar 20; pH 7; TA (gL-1): Tween 20 -10, Peptone 15; $\mathrm{NaCl}$ 5; $\mathrm{CaCl}_{2} 1 ; \mathrm{pH} 7$.

\section{Quantitative enzyme assay of gut and the bacterial isolates}

Fish gut from each feed trial was aseptically removed on $60^{\text {th }}$ day after $36 \mathrm{~h}$ starvation for quantitative assay of cellulase, amylase, and protease and lipase activity of gut enzyme. The gut was homogenized in $10 \mathrm{ml}$ chilled buffered saline to make a suspension and then centrifuged at $4500 \mathrm{rpm}$ for $15 \mathrm{~min}$. The clear supernatant was used 
for assaying various enzyme activities. Selective broth media were used as production media for a quantitative assay of amylase, cellulase, and protease and lipase production of selected bacterial isolates. A loopful of selected strain was inoculated into Tryptone soya broth and incubated for $24 \mathrm{~h}$ at $37^{\circ} \mathrm{C}$. The liquid production medium about $25 \mathrm{~mL}$ was inoculated with $2 \%$ of the inoculums obtained from seed culture. The culture flasks were incubated for $48 \mathrm{~h}$ at $37 \pm 1^{\circ} \mathrm{C}$. After incubation, the contents were centrifuged at $4500 \mathrm{~g}$ for $15 \mathrm{~min}$, at $4^{\circ} \mathrm{C}$ and the cellfree supernatant was used for enzyme assay. Ten fish were harvested from each experimental setup for further analysis.

\section{Amylase assay}

Amylase activity was assayed by the dinitrosalicylic acid ( DNSA) method based on the estimation of reducing sugars at $540 \mathrm{~nm}$ using maltose as the standard (Bernfeld 1955). 1\% of starch in sodium phosphate buffer $(0.1 \mathrm{M}, \mathrm{pH} 7.0)$ acted as substrate for the assay. One amylase unit was defined as the amount of enzyme per milliliter of sample that released one microgram $(\mu \mathrm{g})$ reducing sugar (maltose) per minute.

\section{Cellulase assay}

Cellulase activity was measured according to the method of Denison and Kohen (1977) using 1\% CMC in potassium phosphate buffer $(0.1 \mathrm{M}, \mathrm{pH} 7.0)$ as substrate. The production of reducing sugar (glucose) from CMC substrate as a result of cellulolytic activity was measured at $540 \mathrm{~nm}$ by dinitrosalicylic acid method using glucose as the standard. One cellulase unit was defined as the amount of enzyme per milliliter of sample that released one microgram $(\mu \mathrm{g})$ of reducing sugar (glucose) per minute.

\section{Protease assay}

Protease activity was determined according to Kunitz caseinase assay method using $1 \%$ Casein in sodium phosphate buffer $(0.1 \mathrm{M}, \mathrm{pH}$ 7.0 ) as substrate. One unit of enzyme activity represents the amount of enzyme required to liberate $1 \mu \mathrm{g}$ of tyrosine per milliliter sample under standard assay conditions.

\section{Lipase assay}

Lipase assay was carried out based on titrimetric method using olive oil as a substrate and polyvinyl alcohol (PVA) as an emulsifier [28].

\section{Scanning Electron Microscopy (SEM)}

The gut sections designated for SEM analyses were processed according to Ghosh et al [29]. dehydrated with a graded ethanol series and subsequently freeze dried .The dried cells were sputtered coated with gold, and finally photographed by a scanning device attached to a JEOL JM - 5600 electron microscope at $20 \mathrm{kV}$ accelerating voltage for an electron beam of wavelength 5-6 $\mathrm{nm}$.

\section{Statistical Analysis}

Statistical analysis of the experimental data was made by analysis of variance (ANOVA) followed by Scheffe's F-test for multiple comparison [30].

\section{Results}

Analysis of the bacterial flora in the gastrointestinal tract of the experimental fish showed that the total culturable aerobic gut bacterial population on Schaedler HiVeg TM Agar plate were in the order of fermented ANFL $\left(100000 \times 10^{3} \mathrm{CFU} / \mathrm{g}\right.$ gut tissue $)>$ control $>$ microwave treated $>$ autoclaved ANFL $>$ raw ANFL. The total aerobic bacterial population was found to be least in ozone treated $\left(120 \times 10^{3} \mathrm{CFU} / \mathrm{g}\right.$ gut tissue) and $\mathrm{H}_{2} \mathrm{O}_{2}$ treated ANFL (15x10 $\mathrm{CFU} / \mathrm{g}$ gut tissue) (Table 2).

While enumerating specific enzyme producing bacterial flora, it was observed that the amylolytic strains were highest in microwave treated (4200 x10 CFU/g gut tissue) and fermented ANFL (3300 x10 30 CFU/g gut tissue) incorporated diets, followed by raw autoclaved $>$ ozone $>$ $\mathrm{H}_{2} \mathrm{O}_{2}$ treated ANFL incorporated diets. The cellulolytic population exhibited maximum activity in fermented $\left(48000 \times 10^{3} \mathrm{CFU} / \mathrm{g}\right.$ gut tissue) and autoclaved ANFL ( $30000 \times 10^{3} \mathrm{CFU} / \mathrm{g}$ gut tissue) followed by microwave $>$ raw $>$ ozone $>\mathrm{H}_{2} \mathrm{O}_{2}$ treated ANFL. Lipolytic bacterial flora were detected in the experimental fish and the maximum population density was recorded in fermented $\left(3700 \times 10^{3} \mathrm{CFU} / \mathrm{g}\right.$ gut tissue $)$ and autoclaved ANFL ( $3400 \times 10^{3} \mathrm{CFU} / \mathrm{g}$ gut tissue) followed by raw $>$ microwave treated $>$ ozone $>\mathrm{H}_{2} \mathrm{O}_{2}$ treated ANFL. Proteolytic bacterial flora were found in all the experimental fish and the maximum count was observed in the gut of rohu (Labeo rohita) fed with fermented $\left(27000 \times 10^{3} \mathrm{CFU} / \mathrm{g}\right.$ gut tissue) and microwave treated $\left(24000 \times 10^{3}\right.$ $\mathrm{CFU} / \mathrm{g}$ gut tissue) ANFL followed by raw, autoclaved $>$ ozone $>\mathrm{H}_{2} \mathrm{O}_{2}$ treated ANFL. On comparison with control the protease producing bacterial population in the experimental feeds containing fermented and microwave treated ANFL, were quiet high. Lipase producing bacterial population was similar to control samples in fermented and autoclaved ANFL fed fish guts and low in all other diets (Table 3).

The intensity of extracellular enzyme activity of the intestinal extract of Labeo rohita gut from each experimental feed was assayed quantitatively and represented as shown in Figure 1. All the diets exhibited higher protease activity. Peak specific amylase and cellulase activities were exhibited by gut extracts of microwave and fermented

\begin{tabular}{|c|c|c|c|c|c|}
\hline $\begin{array}{l}\text { Experimental feed (Protein } \\
\text { Source) Diets }\end{array}$ & $\begin{array}{l}\text { Total Bacterial Count } \\
\text { (CFU } \times 10^{3} / \mathrm{g} \text { gut tissue) }\end{array}$ & $\begin{array}{l}\text { Cellulolytic Bacterial Count } \\
\left(\mathrm{CFU} \times 10^{3} / \mathrm{g} \text { gut tissue) }\right.\end{array}$ & $\begin{array}{l}\text { Amylolytic Bacterial Count } \\
\left(\mathrm{CFU} \times 10^{3} / \mathrm{g} \text { gut tissue }\right)\end{array}$ & $\begin{array}{l}\text { Proteolytic Bacterial Count } \\
\left(\text { CFU } \times 10^{3} / \mathrm{g} \text { gut tissue }\right)\end{array}$ & $\begin{array}{l}\text { Lipolytic Bacterial Count } \\
\text { (CFU } \times 10^{3} / \mathrm{g} \text { gut tissue) }\end{array}$ \\
\hline 1.Raw ANFL & $28000^{d}$ & $1500^{e}$ & $300^{e}$ & $20000^{c}$ & $230^{d}$ \\
\hline $\begin{array}{l}\text { 2.Microwave } \\
\text { ANFL }\end{array}$ & $70000^{b}$ & $12000^{d}$ & $4200^{a}$ & $24000^{b}$ & $200^{e}$ \\
\hline 3.Ozonated ANFL & $120^{e}$ & $120^{f}$ & $10^{9}$ & $10^{f}$ & $70^{f}$ \\
\hline 4. $\mathrm{H}_{2} \mathrm{O}_{2}$ treated ANFL & $15^{f}$ & $13^{g}$ & $15^{f}$ & $15^{e}$ & $10^{9}$ \\
\hline 5.Fermented ANFL & $100000^{a}$ & $48000^{a}$ & $3300^{b}$ & $27000^{a}$ & $3700^{b}$ \\
\hline 6.Autoclave ANFL & $70000^{b}$ & $30000^{b}$ & $2000^{c}$ & $15000^{d}$ & $3400^{c}$ \\
\hline Initial ( $0^{\text {th }}$ day) & $40000^{\circ}$ & $23000^{c}$ & $1000^{d}$ & $20000^{c}$ & $4000^{a}$ \\
\hline
\end{tabular}

Results are means of triplicate treatments. Values with different superscript in the same column are significantly different.

Table 2: Aerobic bacterial count in the gut of rohu fed with experimental diet. 
Citation: Sumathi C, Mohana Priya D, Dilli Babu V, Sekaran G (2011) Analysis of Enzyme Activities of the Gut Bacterial Communities in Labeo rohita fed Differentially Treated Animal Fleshing Diets. J Microbial Biochem Technol 3: 112-000. doi:10.4172/1948-5948.1000061

\begin{tabular}{|c|c|c|c|c|c|}
\hline Experimental diets & Bacterial strains & Amylase activity & Cellulase activity & Protease activity & Lipase activity \\
\hline 1.Raw ANFL & $\begin{array}{l}\text { RF3 } \\
\text { RF5 } \\
\text { RF6 }\end{array}$ & $\begin{array}{l}++ \\
+++ \\
++++\end{array}$ & $\begin{array}{l}+++ \\
+++ \\
++\end{array}$ & $\begin{array}{l}+++ \\
+++ \\
+++\end{array}$ & $\begin{array}{l}+++ \\
++ \\
++++\end{array}$ \\
\hline 2.Microwave treated ANFL & $\begin{array}{l}\text { MF1 } \\
\text { MF2 } \\
\text { MF3 } \\
\text { MF6 }\end{array}$ & $\begin{array}{l}- \\
+++ \\
+++ \\
++++\end{array}$ & $\begin{array}{c}+++ \\
+++ \\
- \\
+++\end{array}$ & $\begin{array}{l}++++ \\
+++ \\
+++ \\
++++\end{array}$ & $\begin{array}{l}++ \\
+++ \\
++ \\
-\end{array}$ \\
\hline 3.Ozone treated ANFL & $\begin{array}{l}\text { OF2 } \\
\text { OF3 } \\
\text { OF5 }\end{array}$ & $\begin{array}{l}++ \\
+++ \\
+++\end{array}$ & $\begin{array}{l}++ \\
++ \\
+++\end{array}$ & $\begin{array}{l}+++ \\
+++ \\
+++\end{array}$ & $\begin{array}{l}- \\
++ \\
++\end{array}$ \\
\hline 4. $\mathrm{H} 2 \mathrm{O} 2$ treated $\mathrm{ANFL}$ & $\begin{array}{l}\text { HF4 } \\
\text { HF5 }\end{array}$ & ++ & $\begin{array}{l}++ \\
+++\end{array}$ & $\begin{array}{l}+++ \\
+++\end{array}$ & $\begin{array}{l}++ \\
++\end{array}$ \\
\hline 5.Fermented ANFL & $\begin{array}{l}\text { FF1 } \\
\text { FF2 } \\
\text { FF3 } \\
\text { FF4 } \\
\text { FF5 }\end{array}$ & $\begin{array}{l}++ \\
++++ \\
+++ \\
+++ \\
+++\end{array}$ & $\begin{array}{l}+++ \\
++++ \\
+++ \\
++++ \\
-\end{array}$ & $\begin{array}{l}+++ \\
++++ \\
++++ \\
++++ \\
++++\end{array}$ & $\begin{array}{l}+++ \\
- \\
++ \\
+++ \\
+++\end{array}$ \\
\hline 6.Autoclaved ANFL & $\begin{array}{l}\text { AF1 } \\
\text { AF3 } \\
\text { AF4 } \\
\text { AF5 }\end{array}$ & $\begin{array}{l}++++ \\
++ \\
+++ \\
+++\end{array}$ & $\begin{array}{c}+++ \\
+++ \\
- \\
+++\end{array}$ & $\begin{array}{l}++++ \\
+++ \\
++++ \\
+++\end{array}$ & $\begin{array}{l}- \\
+ \\
+++ \\
+++\end{array}$ \\
\hline 7.Control & $\begin{array}{l}\text { CF2 } \\
\text { CF3 } \\
\text { CF4 }\end{array}$ & $\begin{array}{l}+++ \\
++ \\
+++\end{array}$ & $\begin{array}{c}++ \\
++ \\
-\end{array}$ & $\begin{array}{l}++++ \\
++++ \\
++++\end{array}$ & $\begin{array}{l}++ \\
+++ \\
+++\end{array}$ \\
\hline
\end{tabular}

'+' sign indicates the intensity of enzyme production (zone diameter of $4 \mathrm{~mm}$ ). ++++ , very high; +++ , high; ++ moderate; +, low; -, nil.

Table 3: Qualitative extracellular enzyme activity of bacterial strains isolated from Labeo rohita fish gut fed with experimental diets.

ANFL fed fish than other diets. Specific activity of lipase was found to be highest in the fermented ANFL fed fish and maximum protease activity was observed in fermented ANFL and Microwave treated ANFL fed fish. The protease and lipase activity of the fermented ANFL fed rohu gut extract was similar to control.

The intensity of extracellular enzyme production by the bacterial strains isolated from the gut of rohu was assayed qualitatively (Table 3 ) in which each ' + ' indicates a zone diameter of $4 \mathrm{~mm}$ (radius-2mm). Among these isolates, eight amylase, eight cellulase, nine lipase and fourteen protease producers were selected for quantitative enzyme assay. Peak cellulase (Figure 2) and amylase (Figure 3) activities were exhibited by the bacterial strains FF2 and RF6 isolated from

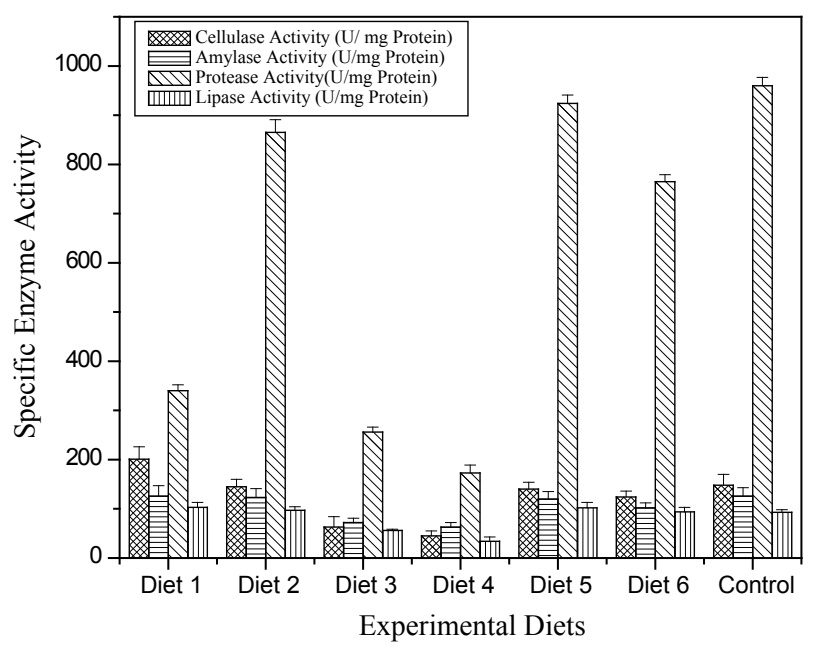

Figure 1: Quantitative Enzyme Assay of gut extract. Diet 1- Raw ANFL; Diet 2- Microwave treated ANFL; Diet 3- Ozone Treated ANFL; Diet 4-Hydrogen Peroxide treated ANFL; Diet 5 -Fermented ANFL; Diet 6 -Autoclaved ANFL; Control -Fish Meal.

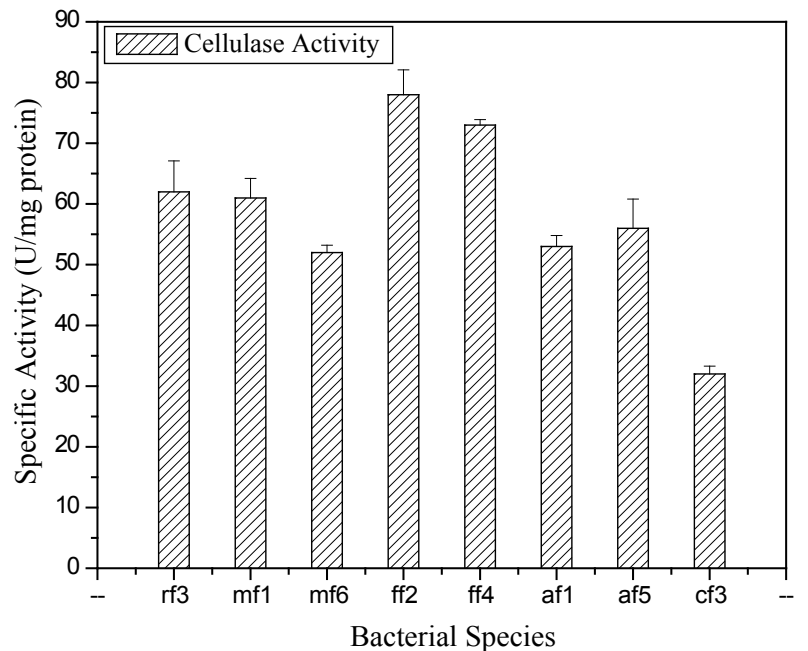

Figure 2: Cellulase activity $(U=\mu$ g glucose liberated $m L-1$ of enzyme extract per min) in different strains (1, RF3; 2, MF1; 3, MF6; 4, FF2; 5, FF4; 6, AF1; 7, AF5; 8, CF3) isolated from experimental diets $1,2,3,6$ and 7 rf from Diet 1 , $\mathrm{mf}$ from Diet 2, ff from Diet 5, af from Diet 6 and cf from Control.

experimental diet groups1 and 5 respectively. Maximum protease (Figure 4) activity was observed in the strain FF5 isolated from experimental diet 5 , followed by the strains CF3 and CF4 isolated from the control groups. The strain $\mathrm{rf6}$ from experimental diet 1 showed highest lipase activity followed by ff5 and cf4 (Figure 5). In the present study, proteolytic bacteria were detected in the gut of all the fish examined and maximum density of proteolytic bacterial population was observed in the experimental diets 5 and $2\left(2.7 \times 10^{7}\right.$ and $2.4 \times$ $10^{7} \mathrm{CFU} \cdot \mathrm{g}^{-1}$ intestinal tissue). However, assay of extracellular protease activity of the bacterial isolates showed highest value in FF5 (287 U), a strain isolated from the diet 5 fed fish gut. SEM analysis of Labeo rohita gut (Figure 6), the arrow marks indicates the position of the bacterial cells attached to the gut wall. 


\section{Discussion}

The factor contributing to the bacterial assemblage is diet [71]. Protein is the dietary macronutrient and energy source whose requirement is prioritized in nutritional studies, either because it represents the highest fish feed cost, or greatly affects specific growth rate $[78,80]$.Digestive enzyme activities of fish are associated with innate feeding habit and diet composition $[81,82]$. Hence, the study of digestive enzymes is an essential step towards understanding the mechanism of digestion and how organisms adapt to changes in the nutritional environment $[83,84]$. The proteinaceous ANFL generated from Leather industry after various treatments physical (autoclave and microwave), chemical $\left(\mathrm{H}_{2} \mathrm{O}_{2}\right.$ and $\left.\mathrm{O}_{3}\right)$ and microbial fermentation were

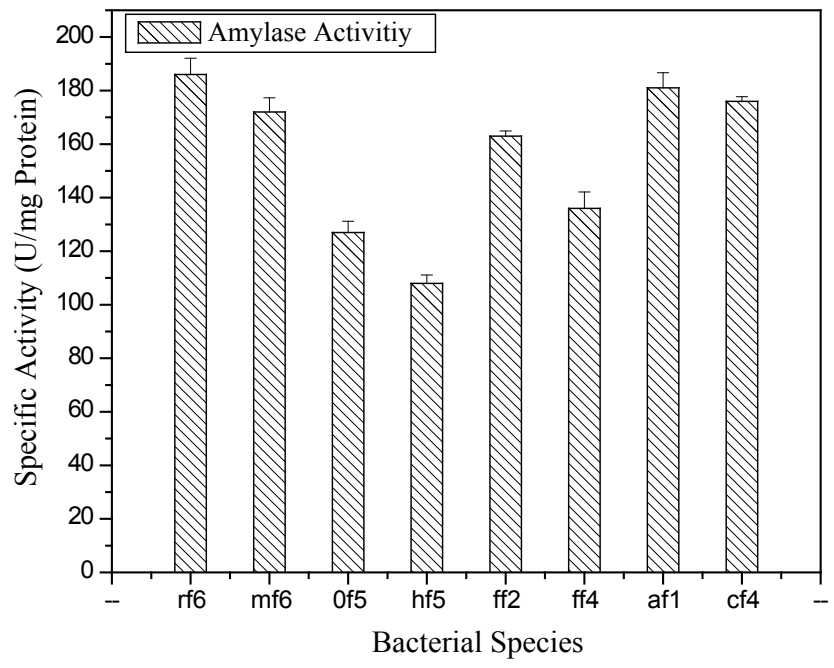

Figure 3: Amylase activity $\left(U=\mu \mathrm{g}\right.$ maltose liberated $\cdot \mathrm{mL}^{-1}$ of enzyme extract per min) in different strains (1, rf6; 2 , mf6; 3 , of $6 ; 4$, hf5; 5 , ff2; 6, ff4; 7, af1; 8 , cf4) isolated from the experimental diets rf from Diet $1, \mathrm{mf}$ from Diet 2 , of from Diet 3, ff from Diet 5, af from Diet 6 and cf from Control.

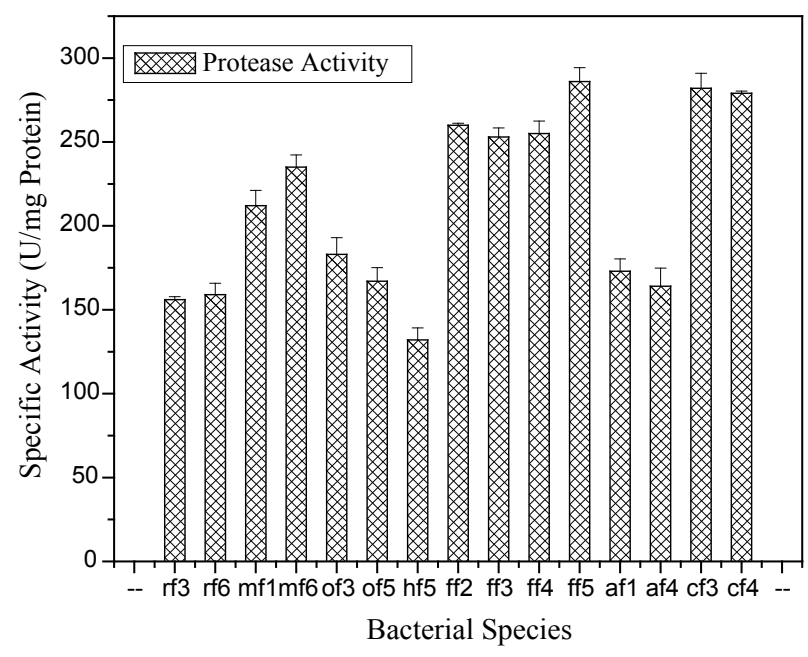

Figure 4: Protease activity $(U=\mu \mathrm{g}$ tyrosine liberated $\cdot \mathrm{mL}-1$ l of enzyme extract per $\mathrm{min}$ ) exhibited in different strains $(1, \mathrm{rf} 3 ; 2, \mathrm{rf} 6 ; 3, \mathrm{mf} 1 ; 4, \mathrm{mf} 6 ; 5$, of $3 ; 6$, of $5 ; 7$, hf5; 8 , ff2; 9, ff3; 10,ff4; 11, ff5; 12, af1; 13, af4; 14, cf3; 15, $\mathrm{cf} 4 ;$ ) isolated from all the experimental diets respectively. If from Diet $1, \mathrm{mf}$ from Diet 2, of from Diet 3, hf from Diet 4, ff from Diet 5, af from Diet 6 and cf from Control.

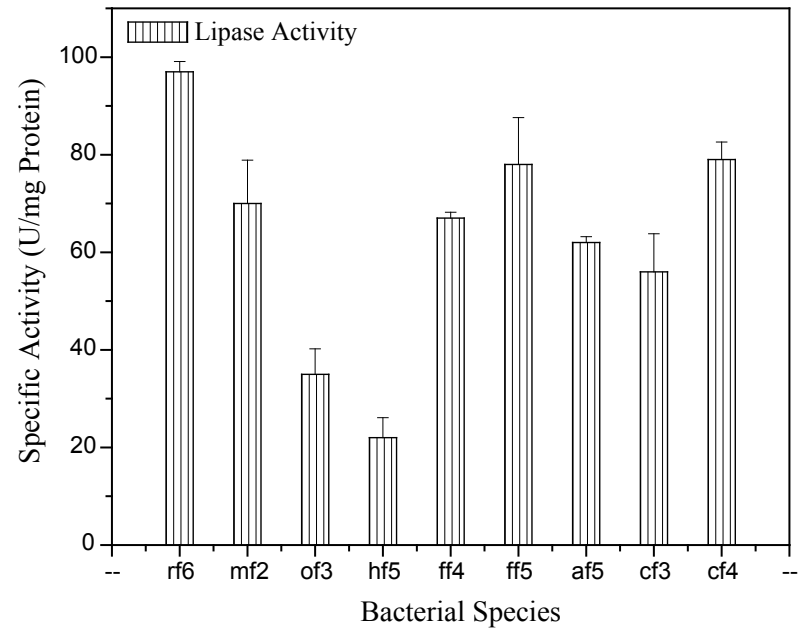

Figure 5: Lipase activity $\left(\mathrm{U}=\right.$ amount of fatty acids released $\mathrm{mL}^{-1}$ of enzyme extract per minute) in the selected strains (1, rf6; 2 , mf2; 3 , of $3 ; 4$, hf5; 5 , ff4; 6 , af5; 7, cf3; 8 , cf4 ;) from all the experimental diets respectively. If from Diet 1, mf from Diet 2, of from Diet 3, hf from Diet 4, ff from Diet 5, af from Diet 6 and cf from Control.

included in diets of Labeo rohita to analyze the ANFL incorporated diet assimilating bacterial population with enzyme producing capacity. The processing techniques of ANFL includes heat treatment to obtain sterile product as defined by Codex Alimentarius (FAO) for the reduction in viable count in ANFL [31]. chemical process through ozonation and hydrogen peroxide treatment which are strong oxidizers that kills micro-organisms by blocking their enzyme control system and deodorizes both gaseous and particulate matter by a oxidative mechanism and removes the contaminants which can destroy the protein resulting in obtaining better level of protein [32-34] and microbial fermentation with mixed culture which is a best approach to obtain the desired product [35].

The gastrointestinal (GI) tract of fish is a complex ecosystem possessing a dense bacterial population levels consisting of aerobic, facultative anaerobic and obligate anaerobic bacteria [64-69].that can be defined as either autochthonous (indigenous) or allochtonous (transient) depending upon its ability to adhere and colonize the mucus layer in the digestive tract $[36,37,70]$.

In the present investigation, the presence of a considerable population of bacterial flora in the gastrointestinal tracts of the fish species is confirmed through SEM analysis and supports the earlier reports that the bacteria entering along with the diet of fish during ingestion may adapt themselves in the gastrointestinal tract to form a symbiotic association and may be considered to have possible contribution in nutritional process of fish via extracellular bacterial enzymes. Moreover, certain strains of bacteria isolated from the gut extract exhibited quantitative amount of amylolytic, cellulolytic, lipolytic and proteolytic activities [15,38-41]. The Fermented ANFL increases protease producing bacterial population on gut and thereby aids in the digestion of proteinaceous diet. On the other hand, the $\mathrm{H}_{2} \mathrm{O}_{2}$ and Ozone (oxidizing and bactericidal agent) treated ANFL had the least bacterial count and low enzyme activity. The complexity and intact structure of raw ANFL minimizes the gut microbial protease activity of fish fed with diet 1 but cellulase and amylase activity were seen due to the presence of rice bran and wheat flour which are plant based natural 


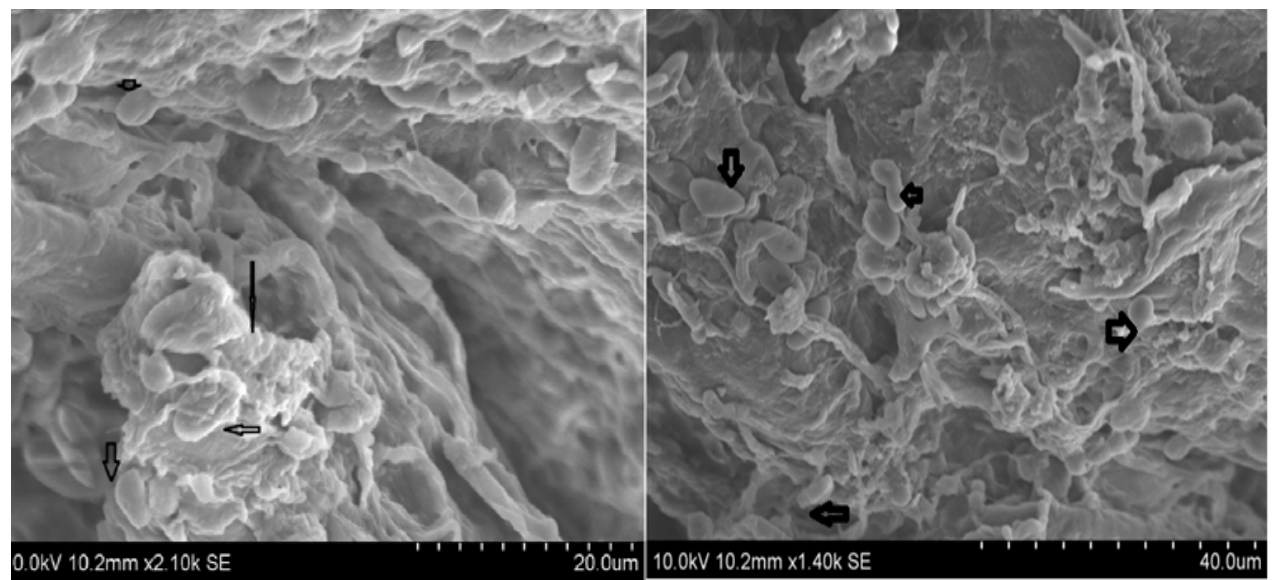

Figure 6: SEM analyses of Labeo rohita fish gut bacterial population. The arrow marks indicates the position of the bacterial cells attached to the gut wall.

diet for the fish. In diet 2 the microwave heat treatment process would have untangled the closely knit collagen structure present in ANFL thereby facilitating its easy uptake from the feed. In the diet 3 and 4 , the native protein present in raw ANFL reduced assimilation; therefore, both the bacterial population and enzyme activity remained dormant (Table 2 and Figure 1). The gut extract of diet 5 fed fish showed maximum protease activity than control fish meal based feed. Elevated bacterial population with synchronized increase in protease activity of Labeo gut fed with fermented ANFL reveals the adaptability of rohu to new protein source. It is further noteworthy to state that diet 5 showed the maximum number of proteolytic bacterial count when compared to all other diet fed fish groups (Table 2). The probable reason could be the introduction of heavy bacterial population exogenously to the gut from the feed containing fermentation bacteria. The fermentation bacteria help the host in digestion of food and give less chance for the pathogens to colonize the gastrointestinal tract. Diet 6 fed fish groups also exhibits protease activity higher than diet1, 3 and 4 but lower than the diet 5. Cellulase, amylase and lipase activities of the gut extracts in all the experimental fish were found to be more or less stable due to the similar feed components in the formulated diet.

Since the experimental diets contain carbohydrate sources such as wheat flour and rice bran considerable population of amylolytic bacterial strains were detected. The highest amylase producing strain RF6 (186 U) was isolated from the experimental diet 1. Similar results have been reported by previous researchers with carbohydrate based feed $[24,42,43]$.

Microbial intestinal cellulase activity has been detected earlier in carp [44]. grass carp [43]. and in [38]. fingerlings. Quantitative assay of the selected strains showed relative cellulase activity due to the presence of natural complex cellulose containing plant products like wheat flour and rice bran in the diet (Figure 2 and Table 3). Hence, the cellulase activity was low in the gut extract compared to that of the proteases due to the formulation of protein rich diets. However, the strains FF2 and FF4 were observed to have the highest activity among all other isolates for cellulase production. These bacterial strains present in the gut might indigenously posses the cellulolytic activity or may have derived due to ingestion of rice bran (plant source).

Although fish have an endogenous source of protease in their digestive tracts, not much attention has been paid to the microbial source of protease in fish. Ghosh et al.[15] suggested that Bacillus circulans, B. pumilus, and B. cereus, isolated from the alimentary canal of Labeo rohita fingerlings were good producers of proteolytic enzymes, though they did not quantify the enzyme activity. Since the experimental diets were protein rich the bacterial strains as well as the gut extracts showed higher protease activity than other enzymes and this corroborates with the prior report wherein increased proteolytic enzyme activity in common carp were observed with bovine-trypsin based diet [45]. Kawai [ 86] reported adaptive changes in the proteolytic enzyme in common carp (Cyprinus carpio) in relation to the type of the diet. The occurrence of proteolytic bacteria in the gut of the isolated fish species seems to support the presence of a diet dependent microbial population [37]. Further these investigations have suggested that microorganisms have a beneficial effect in the digestive processes of fish. A number of studies on the use of proteases to improve the digestibility of feed ingredients in poultry, pigs and cattle have been published. In broiler chickens, the addition of protease to lupin-based [89] or soya bean-based [90, 91] diets resulted in improved digestibility of protein.

The micro flora of the fish gut is generally culturable and occurrence of protease, amylase and cellulase and lipase producing bacterial population is noteworthy in the digestive tract of rohu. Digestive enzyme activities has also been reported earlier using Bacilus $s p$. containing probiotics in common carp [46]. B. subtilis in four livebearing ornamental fishes [47]. Lactobacillus spp. [48] in beluga (Huso huso) and Persian sturgeon (Acipenser persicus) [49] and live yeast in European sea bass larva [50]. Cellulolytic and Amylolytic gut microflora has been reported earlier $[4,38,40,92]$. Protease producing organisms and their activity was observed in the gut of the six ANFL formulated diets fed groups and is highest in the fermented ANFL fed Labeo rohita which may be due to the presence of fermentation facilitating bacterial strains. Furne et al. [87] observed that it is possible to predict the ability of a species to utilize different nutrients based on its digestive enzyme profile. The bacterial diversity in the intestines of abalone fed with artificial food was higher than in individuals fed with sea algae [87] and differed between puffer fish fed a natural diet and those fed with an artificial diet $[71,87]$. The information generated from the present study might contribute towards the research of diet dependent change of micro biota in the gastrointestinal tract of Labeo rohita as well as the low cost feed formulation process utilizing the tannery solid waste as protein source. The study also indicates that there is a distinct microbial source of the digestive enzymes - amylase, cellulase, lipase 
and protease, apart from endogenous sources in fish gut through ANFL administered feed which helps the fish to digest the nutrients well and lead to increase in the total enzyme producing microbial population.

The information generated from the present investigation might contribute to the incorporation of these bacteria in commercial aquaculture as supplement in formulated fish feed or in form of bacteria biofilm to achieve colonization in the fish gut at a higher degree. However, further research involving potent bacterial strains should be conducted for evaluating their efficacy under actual farm conditions. The results are also in agreement with the previous research findings that type of food can influence the enzymatic activity [81,92]. and the bacteria, initially introduced with food, further become adapted to particular gastro-intestinal environmental conditions, and develop as a distinct or transient community of facultative aerobic which, being metabolically active, play an active role in digestive processes [5155]. However, the influence of these bacterial populations on the fish productivity is not known and requires further investigation.

In fish, data pertaining to digestive enzyme activity and profiles have helped overcome nutritional problems associated with formulation of artificial diets that best meet an animals' nutritive capability [86]. The results also present a scope for fish nutritionists to utilize the enzyme-producing bacterial isolates as a probiotic in formulating costeffective aquafeeds, especially for the larval stages when the enzyme system is not efficient. However, further investigations are required to know about the metabolic pathways used by these microorganisms in the alimentary tracts of fish, to explain the lifelong host-microbe homeostasis.

\section{Acknowledgement}

Author, C. Sumathi is grateful to the Director, Central Leather Research Institute, Chennai for providing facilities for carrying out the work.

\section{References}

1. Clements KD, Choat JH (1995) Fermentation in tropical marine herbivorous fishes. Physiol Zoology 68: 355-378.

2. Luczkovich JJ, Stellwag EJ (1993) Isolation of cellulolytic microbes from the intestinal tract of the pinfish, Lagodon rhomboides: size-related changes in diet and microbial abundance. Mar Biol 116: 381-388.

3. Ringo E, Strom E (1994) Microflora of Arctic charr, Salvelinus alpinus (L.): gastrointestinal microflora of free-living fish and the effect of diet and salinity on intestinal microflora. Aquaculture Res 25: 623-629.

4. Sakata (1990) Microflora in the digestive tract of fish and shell-fish, 171-176. In: Lésel R. (ed.) Microbiology in poecilotherms [sic]. Elsevier Science, Amsterdam

5. Olafsen JA (2001) Interactions between fish larvae and bacteria in marine aquaculture. Aquaculture 200: 223-247.

6. Ringo E, Sperstad S, Myklebust R, Mayhew TM, Olsen RE (2006a) The effect of dietary inulin on aerobic bacteria associated with hindgut of Arctic charr (Salvelinus alpinus L.). Aquac Res 37: 891-897.

7. Lésel R (1991) Does a digestive active bacterial flora exist in fish?. In: Kaushik S.J., Luquet P. (eds.) Fish Nutrition in Practice. IVth International Symposium on Fish Nutrition and Feeding, Biarritz (France), 1993. Pp. 655-664, INRA, Paris.

8. Morelli L (2007) In vitro assessment of probiotic bacteria: from survival to functionality. Int Dairy J 17: 1278-1283.

9. Joseph J, Surendran PK, Perigreen PA (1988) Studies on iced storage of cultured rohu - Labeo rohita. Fish. Technol 25: 105-109

10. Horsley RW (1973) The bacterial flora of the Atlantic salmon Salmo salar L. in relation to its environment. J Appl Bacteriol 36: 377-386.
11. Allen DA, Austin B, Colwell R (1983) Numerical taxonomy of bacterial isolates associated with a freshwater fishery. J Gen Microbiol 129: 2043-2062.

12. Moriarty DJW (1990) Interactions of microorganisms and aquatic animals, particularly the nutritional role of the gut flora. In: Le'sel R, Ed, Microbiology in Poecilotherms. Elsevier, Amsterdam, 217-222.

13. Spanggaard B, Jorgensen F, Gram L, Huss HH (1993) Antibiotic resistance in bacteria isolated from three freshwater fish farms and an unpolluted stream in Denmark. Aquaculture 115: 195-207.

14. Alexander SCC, Hashim R, Lee CY, Ahyaudin BA (2002) Partial characterization and activities of proteases from the digestive tract of discus fish Symphysodon aequifasciata. Aquaculture 203: 321-333.

15. Ghosh K, Sen SK, Ray AK (2002) Characterization of bacilli isolated from gut of rohu, Labeo rohita, fingerlings and its significance in digestion. J Appl Aquac 12: $33-42$.

16. Nibedita K, Ghosh K (2008) Enzyme Producing Bacteria in the Gastrointestinal Tracts of Labeo rohita (Hamilton) and Channa punctatus (Bloch). Turk J Fisheries Aquatic Sci 8: 115-120.

17. Ray AK, Roy T, Mondal S, Ringø E (2010) Identification of gut-associated amylase, cellulase and protease-producing bacteria in three species of Indian major carps. Aquac Res 41: 1462-1469.

18. Clements KD (1997) Fermentation and gastrointestinal microorganisms in fishes. In: Mackie R.I.,White B.A. (eds.) Gastrointestinal microbiology. Vol. 1. Gastrointestinal Ecosystems and fermentations. Chapman \& Hall, New York. 156-198.

19. Bakke-McKellep AM, Penn MH, Salas PM, Refstie S, Sperstad S, et al. (2007) Effects of dietary soyabean meal, inulin and oxytetracycline on intestinal microbiota and epithelial cell stress, apoptosis and proliferation in the teleost Atlantic salmon (Salmo salar L.). Br J Nutr 97: 699-713.

20. Bjornsdottir R, Johannsdottir J, Coe J, Smaradottir H, Agustsson T, et al (2009) Survival and quality of halibut larvae (Hippoglossus hippoglossus L.) in intensive farming: possible impact of the intestinal bacterial community. Aquaculture 286: 53-63.

21. Kim DH, Brunt J, Austin B (2007) Microbial diversity of intestinal contents and mucus in rainbow trout (Oncorhynchus mykiss). J Appl Microbiol 102: 1654 1664.

22. Ringo E, Sperstad S, Myklebust R, Refstie S, Krogdahl A (2006b) Characterisation of the microbiota associated with intestine of Atlantic cod (Gadus morhua L.): the effect of fish meal, standard soybean meal and a bioprocessed soybean meal. Aquaculture 261: 829-841.

23. Bairagi A, Ghosh KS, Sen SK, Ray AK (2002) Enzyme producing bacterial flora isolated from fish digestive tracts. Aquacult Int 10: 109-121.

24. Sabyasachi, Mondal., Tanami, Roy. , Sukanta, K., Sen , and Arun, K. Ray. 2008 . Distribution of enzyme-producing bacteria in the digestive tracts of some freshwater fish, Acta Ichthyol Piscat., 38, 1-8.

25. Stavric S, Kornegay T (1995) Microbial probiotics for pigs and poultry. In: R.J. Wallace and A. Chuson,(Eds.), Biotechnology in Animal Feeds and Anima Feeding. Weinheim, New York: 205-231.

26. Sissons JW (1989) Potential of probiotic organisms to prevent diarrhoea and promote digestion in farm animals-a review. J Sci Food Agric 49: 1-13.

27. Denise K, Timothy K, Rustam A (2007) Importance of microbial colonization of the gut in early life to the development of immunity. Mutation Res 622: 58-69.

28. Ota Y, Yamada K (1966) Lipase from Candida paralipolytica: Part 1 Anionic surfactant as the essential activator in the systems emulsified by polyvinyl alcohol. Agri Biol Chem 30: 351-358.

29. Ghosh K, Roy M, Kar N, Ringo E (2010) Gastrointestinal Bacteria In Rohu Labeo Rohita (Actinopterygii:Cypriniformes: Cyprinidae): Scanning Electron Microscopy and Bacteriological Study. Acta Ichthyol Piscat 40: 129-135.

30. Das D, Das A (1993) Statistics in Biology and Psychology, Academic Publishers, Calcutta, India.

31. Tahir A, Mateen B, Univerdi S, KaraGoban O, Zengin M (2009) Simple method 
to study the mechanism of thermal and non thermal bactericidal action of microwave radiations on different bacterial species. J Bacteriol Res 1: 58-63.

32. Behrouz Mosayebi Dehkordi., Neda Zokaie .,2010,W Acad Sci, Engg . Technol. 62

33. Eugene, McGahan Chaim Kolominskas, Kelsey Bawden, Robin Ormerod (2002) Strategies to reduce odour emissions from meat chicken farms Proceedings. Poultry Information Exchange

34. Sopher CD, Graham DM, Strasser JH, Rice RG (2002) The Use of Ozone in Production Agriculture and Food Processing, Soil Science Society of North Carolina: Summary of the 45th Annual Meeting 15: $19-22$

35. Daeschel M, Andersson R, Fleming H (1987) Microbial ecology of fermenting plant materials. FEMS Microbiology Letters 46: 357-367.

36. Austin B (2002) The bacterial microflora of fish. Scientific World Journal 2: 558-572.

37. Ringo E, Olsen RE, Mayhew TM, Myklebust R (2003) Electron microscopy of the intestinal microflora of fish. Aquaculture 227: 395-415.

38. Lesel R, Fromageot C, Lesel M (1986) Cellulase digestibility in grass carp, Ctenopharyngodon idella and in gold fish, Carassius auratus. Aquaculture 54 : $11-17$.

39. Saha S, Roy RN, Sen SK, Ray AK (2006) Characterization of cellulaseproducing bacteria from the digestive tract of tilapia, Oreochromis mossambica (Peters) and grass carp,Ctenopharyngodon idella (Valenciennes). Aquac Res 37: 380-388.

40. Stickney RR, Shumway SE (1974) Occurrence of cellulase activity in the stomachs of fish. J Fish Biol 6: 779-790.

41. Hamid A, Sakata T, Kakimoto D (1979) Microflora in the alimentary tract of grey mullet. IV. Estimation of enzyme activities of the intestinal bacteria. Bull. Japanese Society of Scientific Fisheries (Nippon Suisan Gakkaishi) 45: 99 106.

42. Das KM Tripathi SD (1991) Studies on the digestive enzymes of grass carp, Ctenopharyngodon idella (Val.). Aquaculture 92: 21-32.

43. Dhage KP (1968) Studies on the digestive enzymes in the three species of the major carps .Indian Biol Sci J 11: 63-74

44. Shcherbina MA, Kazlauskiene OP (1971) The reaction of the medium and the rate of absorption of nutrients in the intestine of carp. Ichthyology $\mathrm{J} 11: 81-85$.

45. Dabrowski K, Glogowski J (1977) Studies on the role of exogenous proteolytic enzymes in digestion processes in fish. Hydrobiologia 54: 129-134.

46. Wang YB, Xu ZR (2006) Effect of probiotic for common carp (Cyprinus carpio) based on growth performance and digestive enzyme activities. Ani Feed Sci Technol 127: 283-292.

47. Ghosh S, Sinha A, Sahu C (2008) Dietary probiotic supplementation in growth and health on live-bearing ornamental fishes. Aquacult Nutr 14: 289-299.

48. Suzer C, Coba D, Kamaci SO, Saka S, Firat K, et al. Lactobacillus sps bacteria as probiotic in gilthead seabream sparus aurata $L$ larvae effects on growth performance and digestive enzyme activities. Aquaculture 280: 140-145.

49. Askarian F, Kousha A, Salma W, Ringo E (2011) The effect of lactic acid bacteria administration on growth, digestive enzyme activity and gut microbiota in Persian sturgeon (Acipenser persicus) and beluga (Huso huso) fry. Aqualt Nutr 17: 488-497.

50. Tovar-Ramírez D, Mazurais D, Gatesoupe JF, Quazuguel P, Cahu CL (2010) Dietary probiotic live yeast modulates antioxidant enzyme activities and gene expression of sea bass (Dicentrarchus labrax) larvae. Aquaculture 300: 142 147.

51. Caruso G, Denaro MG, Genovese L (2009) Digestive enzymes in some teleost species of interest for mediterranean aquaculture. The Open Fish Science Journal 2: 74-86.

52. MacDonald NL, Stark JR, Austin B (1986) Bacterial microflora in the gastrointestinal tract of Dover sole (Solea solea L.), with emphasis on the possible role of bacteria in the nutrition of the host. FEMS Microbiology Letters 35: 107111.
53. Cahill M (1990) Bacterial flora of fishes: a review. Microbiol Ecol 19: 21-41.

54. Stevens CE, Hume ID (1998) Contributions of microbes in vertebrate gastrointestinal tract to production and conservation of nutrients. Physiol Rev 78: 393-427.

55. Sera H, Ishida Y, Kadota M (1974) Bacterial flora in the digestive tracts of marine fish. In: Colwell RR, Morita RY, Ed. Effect of the ocean environment on microbial activities. University Park Press. 467-490.

56. Jacob MB, Gerstein MJ (1960) Hand book of Microbiology. D. Van Nostrand Co. Inc. Princeton. New Jersey, USA, 61.

57. Rehman FU, Aslam M, Tariq MI, Shaheen A, Sami AJ, et al. (2009) Isolation of cellulolytic activities from Tribolium castaneum (red flour beetle). African $\mathrm{J}$ Biotechnol 23: 6710-6715.

58. Ringo E, Strom E, Tabachek JA (1995) Intestinal microflora of Salmonids: A review. Aquacult Res 26: 773-789.

59. Thompson FL, Hoste B, Thompson CC, Goris J, Gomez-Gil B, et al. (2002) Enterovibrio norvegicus gen. nov., sp. nov., isolated from the gut of turbot (Scophthalmus maximus) larvae: a new member of the family Vibrionaceae. Internl J Syst Evol Microbiol 52: 2015-2022.

60. Vine NG, Leukes WD, Kaiser H (2006) Probiotics in marine larviculture. FEMS Microbiol Reviews 30: 404-427.

61. Shakila RJ, Vyla SAP, Saravana KR., Jeyasekaran G, Jasmine I (2006) Stability of chloramophenicol residues in shrimp subjected to heat processing treatments. Food Microbiol 23: 47-51.

62. Olafsen JA (2001) Interactions between fish larvae and bacteria in marine aquaculture. Aquaculture 200: 223-247.

63. Izvekova GI, Izvekov El, Plotnikov AO (2007) Symbiotic microflora in fishes of different ecological groups. The Biological Bulletin 34: 610-618.

64. Pond MJ, Stone DM, Alderman DJ (2006) Comparison of conventional and molecular techniques to investigate the intestinal microflora of rainbow trout (Oncorhynchus mykiss). Aquaculture 261: 194-203.

65. Holben WE, Williams P, Gilbert MA, Saarinen M, Sarkilahti LK, et al. (2002) Phylogenetic analysis of intestinal microflora indicates a novel Mycoplasma phylotype in farmed and wild salmon. Microbial Ecol 44: 175-185

66. Huber I, Spanggaard B, Appel KF, Rossen L, Nielsen T, et al. (2004) Phylogenetic analysis and in situ identification of the intestinal microbial community of rainbow trout (Oncorhynchus mykiss, Walbaum). J Appl Microbiol 96: 117-132.

67. Seppola M, Olsen RE, Sandaker E, Kanapathippillai P, Holzapfel W, et al. (2006) Random amplification of polymorphic DNA (RAPD) typing of carnobacteria isolated from hindgut chamber and large intestine of Atlantic cod (Gadus morhua L.). Syst Appl Microbiol 29: 131-137.

68. Vandenberghe J, Thompson FL, Gomez-Gil B, Swings J (2003) Phenotypic diversity amongst Vibrio isolates from marine aquaculture systems. Aquaculture 219: 9-20.

69. Verner-Jeffreys DW, Shields RJ, Bricknell IR, Birkbeck TH (2003) Changes in the gut-associated microflora during the development of Atlantic halibut (Hippoglossus hippoglossus L.) larvae in three British hatcheries. Aquaculture 219: 21-42.

70. Onarheim AM, Raa J (1990) Characteristics and possible biological significance of an autochthonous flora in the intestinal mucosa of sea-water fish. In: Le'sel, R. (Ed.), Microbiology in Poecilotherms. Elsevier Science Publishers Amsterdam, pp. 197-201

71. Yang G, Bao B, Peatman E, Li H, Huang L (2007) Analysis of the composition of the bacteria community in puffer fish Takifugu obscures. Aquaculture 262 183-191.

72. Gram L, Huss HH (1996) Microbiological spoilage of fish and fish products. Int J Food Microbiol 33: 121-137.

73. Uys W, Hecht T (1987) Assays on the digestive enzymes of Sharptooth Catfish, Clarias gariepinus (Pisces: Claridae). Aquaculture 63: 301-313.

74. Korsnes K, Nicolaisen O, Skar CK, Nerland AH, Bergh O (2006). Bacteria in 
Citation: Sumathi C, Mohana Priya D, Dilli Babu V, Sekaran G (2011) Analysis of Enzyme Activities of the Gut Bacterial Communities in Labeo rohita fed Differentially Treated Animal Fleshing Diets. J Microbial Biochem Technol 3: 112-000. doi:10.4172/1948-5948.1000061

the gut of juvenile cod Gadus morhua fed live feed enriched with four different commercial diets. ICES J Marine Sci 63: 296-301.

75. Gjerde B, Padala VGK Reddy, Kanta D. Mahapatra , Jatendra N. Saha, Ranjit K. Jana, et al. (2002) Growth and survival in two complete diallele crosses with five stocks of Rohu carp (Labeo rohita). Aquaculture 209: 103-115

76. Tacon AGJ (1993) Feed Ingredients for Warm Water Fish: Fish Meal and Other Processed Feedstuffs. FAO, Rome, Italy., (FAO Fisheries Circular, 856).

77. Webster CD Tidwell JH, Tiu LS (1995) Use of soybean meal as partial or total substitute of fish meal in diets for blue catfish (Ictalurus furcatus). Aquatic Living Resources 8: 379-384.

78. Hofer R, Köck G (1989) Method for quantitative determination of digestive enzymes in fish larvae. Pol Arch Hydrobiol 36: 439-441.

79. Yaniv Hakim, Zehava Uni, Gideon Hulata, Sheenan Harpaz (2006) Evaluation of Artificial Diets for Cultured Fish. Aquaculture 257: 420-428

80. Al Hafedh YS (1999) Effects of dietary protein on growth and body composition of Nile tilapia Oreochromis niloticus L. Aquacult Res 30: 385-339

81. Ray AK (1988) On the digestive enzymes in three Indian freshwater perches in relation to food and feeding habits. Journal of the Fisheries Society Indonesian 20: $1-5$

82. Grewal R, Mahmood A (2004) Coordinate secretion of alkaline phosphatase into serume and intestine in fat-fed rats. Indian J Gastroenterol 23: 175-177.

83. Klein S, Cohn SM, Alpers DH (1998) The alimentary tract in nutrition. In: Shils, M.E., Olson, A.J., Shike, M., Ross, A.C. (Eds.), Modern Nutrition in Health and Disease 605-630.

84. Sunde J, Eiane SA, Rustad A, Jensen HB, Opstvedt J, et al. (2004) Effect of fish feed processing conditions on digestive protease activities, free amino acid pools, feed conversion efficiency and growth in Atlantic salmon (Salmo salar L.). Aqua Nutr 10: 261-277.

85. Austin , B . 2006. The bacterial microflora of fi sh. Sci. World J. 6, 931 - 945.

86. Kawai S, Ikeda S (1972) Studies on digestive enzymes of fishes. Effect of dietary change on the activities of digestive enzymes in carp intestine. Bull Jpn Soc Sci Fish 38: 265-270.

87. Furne M, Hidalgo MC, Lopez A, Garcia-Gallego M, Morales AE, et al. (2005) Digestive enzymeactivities in Adriatic sturgeon Acipenser naccarii and rainbow trout Oncorhynchus mykiss. A comparative study. Aquaculture 250: 391-398.

88. Tanaka R, Ootsubo M, Sawabe T, Ezur Y, Tajima K (2004) Biodiversity and in situ abundance of gut microflora of abalone (Haliotis discus hannai) determined by culture-independent techniques. Aquaculture 241: 453-463.

89. Rubio LA, Brenes A, Centeno C (2003) Effects of feeding growing broiler chickens with practical diets containing sweet lupin (Lupinus angustifolius) seed meal. British Poultry Science 44: 391-397.

90. Marsman GJP, Gruppen H, Ven Der Poel AFB, Kwakkel RP,Verstegen MWA et al. (1997) The effect of thermal processing and enzyme treatments of soybean meal ongrowth performance, ileal nutrient digestibilities, and chyme characteristics in broiler chicks. Poultry Science 76: 864-872.

91. Ghazi S, Rooke JA, Galbraith H, Bedford MD (2002) The potential for the improvement of the nutritive value of soybean meal by different proteases in broiler chicks and broiler cockerels. British Poultry Science 43: 70-77.

92. Saha A., Ray, A.K., 1998. Cellulase activity in rohu fingerlings. Aquacult Int. 6, 281-291. 